\title{
Radical management of aggressive lesions: a case report of recurrent ameloblastoma
}

\author{
Abordagem radical de lesões agressivas: relato de caso de ameloblastoma recorrente
}

Carlos Henrique de CARVALHO E SOUZA ${ }^{1}$

Jessyca Leal Moura FÉ1

Lucas Lopes Araújo SOUSA ${ }^{1}$

Márcia Socorro Da Costa BORBA²

Simone Sousa Lobão Veras BARROS 1

Maria Cândida de Almeida LOPES'

\begin{abstract}
Ameloblastoma is an aggressive, benign odontogenic tumor of epithelial origin. Approximately 1-3\% of all tumors and cysts of the maxillary bones are ameloblastomas. They grow at a slow but persistent rate and are mainly located in the ramus of the mandible. They are occasionally associated with the presence of an impacted third molar. Ameloblastomas are characterized by aggressive infiltration of the surrounding tissue. There may be a high local recurrence rate when the tumor is not properly removed, due to remaining tumor cells. This article reports a case of a multicystic ameloblastoma that had been previously treated with conservative therapy which failed and resulted in recurrence eight years later. Clinical examination showed extensive bone resorption in the right hemi-mandible region. Incisional biopsy and histopathological examination was carried out to confirm the diagnosis. The proposed treatment was total en bloc resection involving the right hemi-mandible, and the region of central and lateral left incisors with a two-centimeter safety margin. Radical surgical protocol with wide margin of safety must be adopted in order to prevent the recurrence of these aggressive tumors.
\end{abstract}

Indexing terms: Ameloblastoma. Odontogenic cysts. Recurrence.

\section{RESUMO}

O ameloblastoma é um tumor odontogênico benigno, porém agressivo, de origem epitelial, constituindo cerca de 1-3\% de todos os tumores e cistos da mandíbula. Apresenta crescimento lento e persistente, localizado na maior parte dos casos na área de ramo de mandíbula e ocasionalmente associado com terceiros molares inclusos. As lesões são caracterizadas por uma infiltração agressiva para o tecido adjacente e as células tumorais restantes podem levar a morbidades múltiplas de recorrência. Dessa forma, pode ocorrer uma elevada taxa de recorrência local se não for adequadamente removido. Este artigo relata um caso de ameloblastoma multicístico previamente tratado com terapia conservadora que resultou no insucesso do tratamento e recidiva da lesão após oito anos. O exame clínico demonstrou extensa reabsorção óssea na região de hemimandíbula direita. Foi realizada biópsia incisional e exame histopatológico para confirmação diagnóstica. O tratamento proposto foi a ressecção total em bloco envolvendo além de hemimandíbula direita, a região de elementos dentários 31 e 32 com margem de segurança de dois centímetros. O protocolo radical cirúrgico com boa margem de segurança deve ser a opção para prevenir a recidiva destes tumores agressivos.

Termos de indexação: Ameloblastoma. Cistos odontogênicos. Recidiva.

\section{INTRODUCTION}

Ameloblastoma is an aggressive benign odontogenic tumor of epithelial origin that originates from remnants of the dental lamina and dental organ (odontogenic epithelium). It presents a slow and persistent growth and is the most common (about 1-3\% of all tumors and cysts) odontogenic tumor of the jaw bones, mostly located in the ramus of the mandible. It is occasionally associated with impacted third molars'.

Its incidence peak is in the third and fourth decade of life, with no gender preference and it is most common in black individuals ${ }^{2-3}$. The ratio of ameloblastoma of the mandible to maxilla is 5 to 1 , with higher sensitivity in the mandible ${ }^{4}$.

Some manifestations associated with this tumor include: painless swelling, facial asymmetry, dental impaction, dental displacement, dental mobility, root resorption, divergence of roots, occlusal interferences and dental extrusion ${ }^{5}$.

Clinically, ameloblastomas can be classified into three types: unicystic, multicystic (or solid), and peripheric ${ }^{6}$. Histologically, the most common variants are follicular and plexiform. Other types include acanthomatous and granular cell ameloblastomas. Uncommon variants include cellular, basal desmoplastic, clear cell, keratoameloblastoma and papilliferous ameloblastoma ${ }^{5,7}$.

\footnotetext{
${ }^{1}$ Universidade Federal do Piauí, Curso de Odontologia, Programa de Pós-Graduação em Odontologia. Campus Universitário Ministro Petrônio Portela, Iningá, 64049-550, Teresina, PI, Brasil. Correspondência para / Correspondence to: CH CARVALHO E SOUZA. E-mail: < carloshcs88@hotmail.com >.

${ }^{2}$ Faculdade Integral Diferencial, Curso de Odontologia. Teresina, PI, Brasil.
} 
Although various methods of treatment have been suggested, the primary choice for multicystic or solid ameloblastomas is the complete removal of the lesion, while the unicystic type may be successfully treated by enucleation or marsupialization?.

The purpose of this article is to emphasize the importance of a radical approach for the treatment of multicystic ameloblastomas, by reporting a case of recurrence that had been treated with conservative therapy.

\section{CASE REPORT}

A black 66-years-old patient was referred to a private dental clinic complaining of pain in the right hemi-mandible region. During anamnesis, the patient reported having already undergone two surgeries in that region to remove lesions, but the pain had returned not long after the surgeries. The first surgery was carried out eight years earlier and the second two years earlier. There was no documentation of prior treatment nor biopsy or histopathological examination to verify the diagnosis.

The radiographic examination revealed extensive bone resorption in the right hemi-mandible region. The patient had no facial asymmetry, but the clinical intraoral examination of the region had a tumoral aspect.

Incisional biopsy was requested for histological examination and the diagnosis was follicular ameloblastoma (Figure 1). A computed tomography revealed the extension of the bone resorption (radiolucent area) and the multicystic aspect of the lesion (Figure $2 \mathrm{~A}$ and $\mathrm{B})$. A prototype of the patient's mandible was manufactured for surgical planning (Figure $2 C$ and $D$ ).

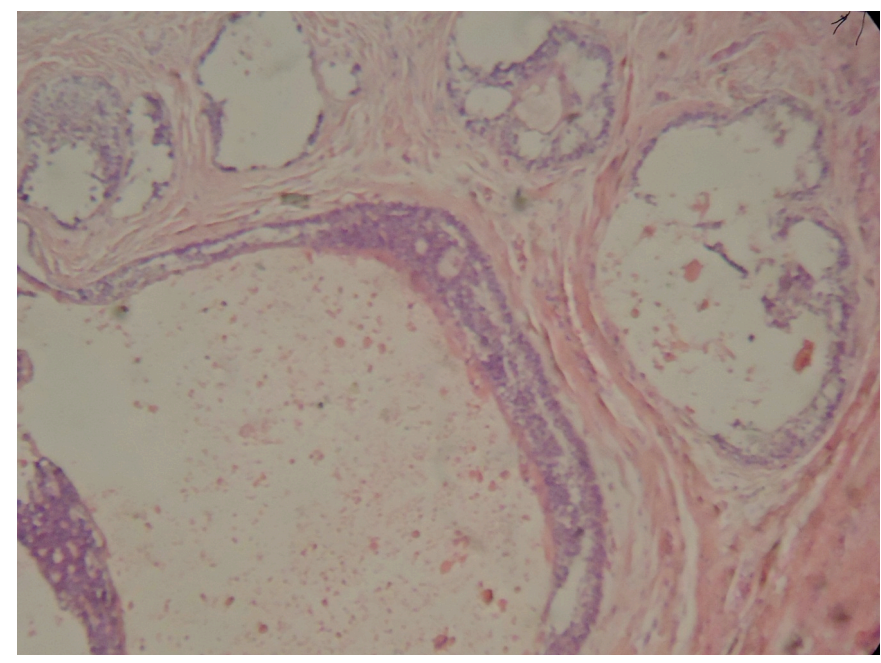

Figure 1. Presence of islets containing cells with spindle and stellate characteristics, surrounded by fibrous connective tissue. Multicystic aspect with follicular classification.

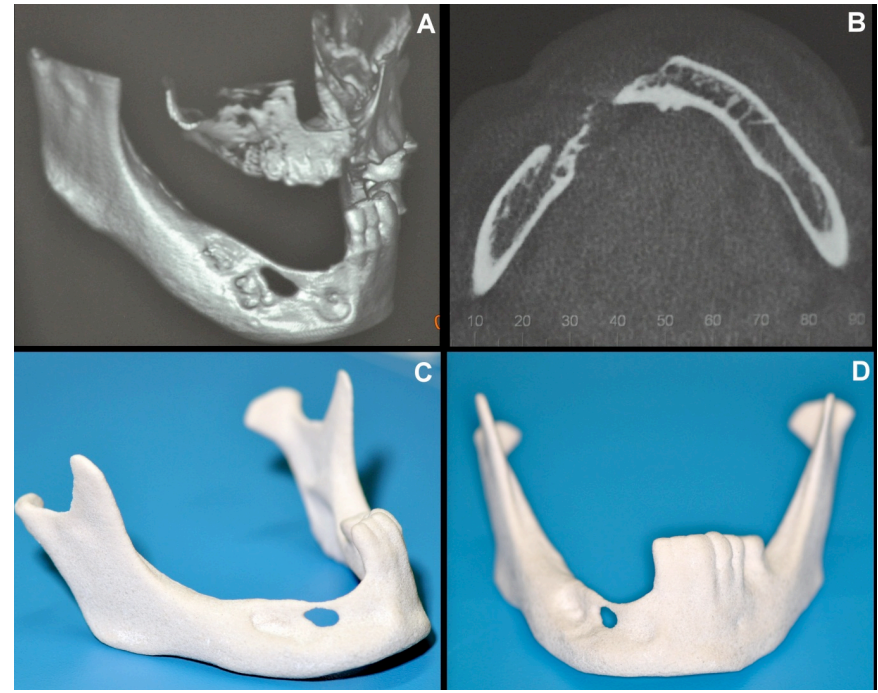

Figure 2. A and B - Computed tomography showing the extent of bone resorption (radiolucent area) and multicystic aspect. C and D - Prototype of the patient's mandible for surgical planning.

Surgery was carried out in a hospital setting. A total en bloc resection was carried out, involving the right hemimandible, the area of the central and lateral left incisors and a two centimeters safety margin (Figure $3 \mathrm{~A}, \mathrm{~B}$ and C). A $2.7 \mathrm{~mm}$ titanium reconstruction plate was prepared using the prototype and fixed with titanium screws were inserted into the surgical resection region to ensure the mandibular outline and stability after surgery (Figure $3 \mathrm{D}$ ).

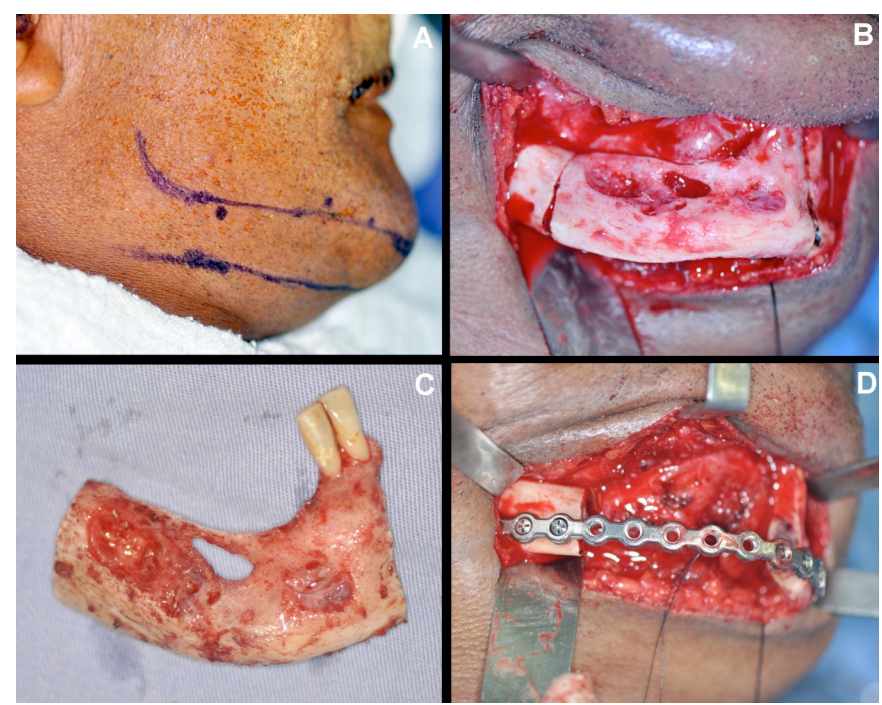

Figure 3. A - Demarcation of the surgical incision. B - Total en bloc resection of right hemi-mandible with a safety margin. C - Surgical specimen removed. D - Implantation of titanium plate for mandibular stabilization.

After the surgical procedure, a panoramic radiograph was carried out in order to assess the fixation of the titanium plate (Figure 4). The patient 
had no alteration of facial movements after surgery, demonstrating the preservation of the facial nerve (Figure $5 \mathrm{~A}$ and $\mathrm{B}$ ). Figure $5 \mathrm{C}$ shows the intraoral aspect of the patient two months after surgery.

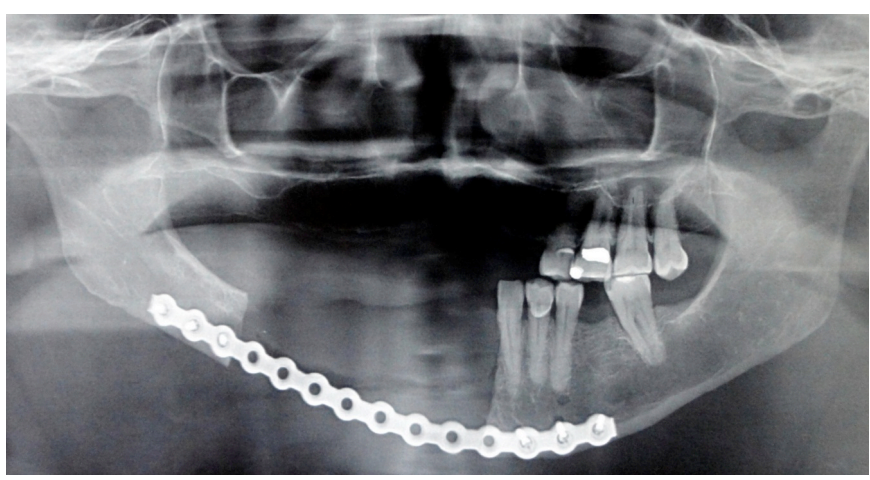

Figure 4 - Post-surgical panoramic radiograph showing adequate fixation of the titanium plate.

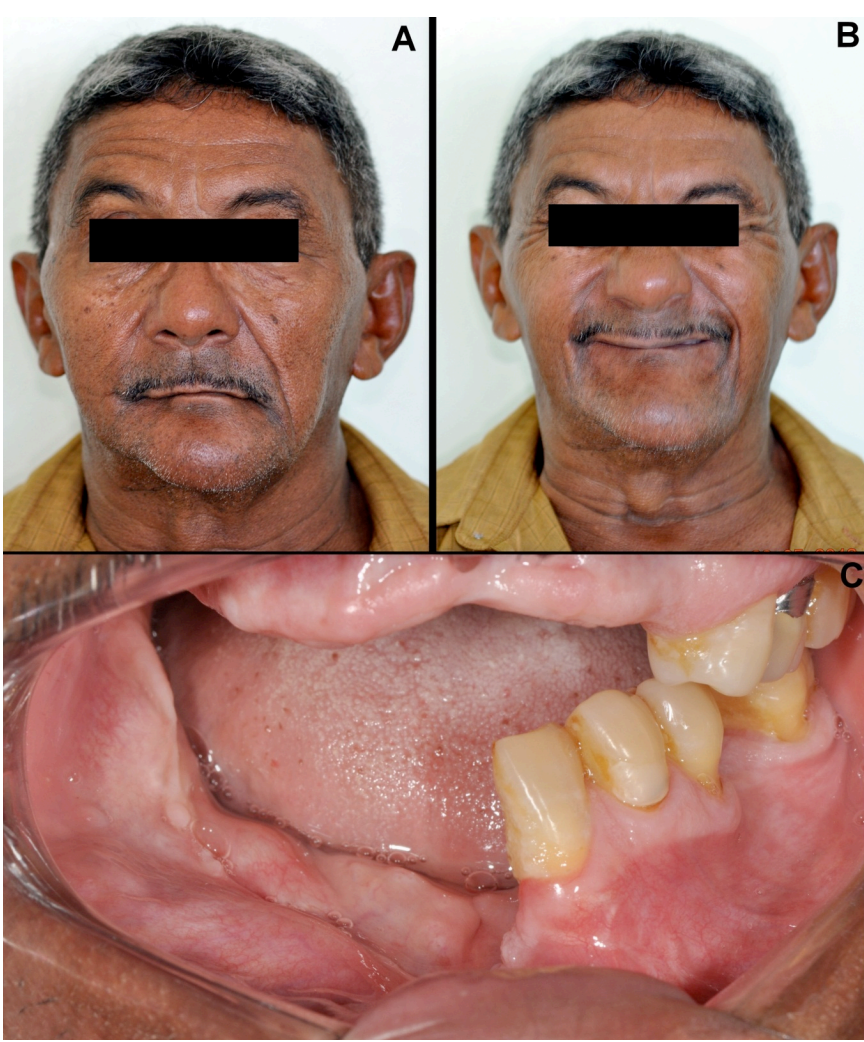

Figure $\mathbf{5}$ - A and B Patient with normal facial expressions, indicating preservation of the facial nerve. C - Intraoral appearance two months after surgery.

The patient was informed that his case report would be submitted for publication and he gave authorization by signing a free and informed consent.

\section{DISCUSSION}

Although ameloblastoma is a benign tumor, its treatment is difficult due to its aggressive behavior, the potential for local invasion and tendency to recur ${ }^{2,8}$. More than $50 \%$ of recurrences occur within the first five years after the primary surgery ${ }^{4}$.

Unicystic ameloblastoma has a fibrous connective tissue capsule and therefore has a much lower rate of recurrence. The solid or multicystic ameloblastoma has a tendency to be locally invasive and has a high recurrence rate when not properly removed?.

The treatment planning of ameloblastoma should take into consideration the growth characteristics of the tumor in order to remove it and to include the surrounding tissue. Two treatment strategies are reported in the literature: conservative and radical procedures. Non-radical surgical procedures, such as enucleation and curettage, are mentioned as useful in unicystic ameloblastomas, especially in children and young patients. Other treatment modalities have also been proposed, such as cryotherapy, electrocautery, sclerotherapy and radiotherapy ${ }^{10}$.

Hong et al. ${ }^{11}$ and Nakamura et al. ${ }^{12}$ showed a high ameloblastoma recurrence rate after conservative treatment protocols. Therefore, in the case of solid and multicystic ameloblastoma, the treatment option should be radical treatment with a 1.5 to $2 \mathrm{~cm}$ safety margin ${ }^{13}$, because these lesions are characterized by aggressive infiltration into the surrounding tissue and remaining tumor cells may lead to multiple recurrence comorbidities ${ }^{14}$.

This case demonstrates the limitations of conservative therapy in a case of multicystic ameloblastoma; the previous treatment proposed was unable to solve the problem. This confirms that extensive and aggressive tumors require a more radical approach, as was carried out in this case ${ }^{15}$.

The recurrence rates of different surgical procedures revealed relatively high rates for patients treated with marsupialization followed by enucleation without bone curettage $(45.5 \%)$ when compared with enucleation with bone curettage (18.2\%). The recurrence rates after radical surgery and conservative treatment were 7.1 and $33.3 \%$, respectively.

However, the degree of resection of the aggressive treatment of a tumor is variable and depends on the location and extension of the ameloblastoma. In addition, surgical planning should also assess the degree of morbidity and the patient's quality of life after surgery ${ }^{16}$. Removing the tumor with a safety margin can cause facial deformity with 
consequent aesthetic and functional consequences, which may jeopardize the patient's self-esteem.

Thus, radical therapy has drawbacks, such as the difficulty of rehabilitation, and may often require reconstruction with vascularized grafts. Other forms of alveolar reconstruction include autogenous bone graft, guided bone regeneration and the use of alloplastic materials ${ }^{9}$. In this case report, a vascular graft was part of treatment plan for future rehabilitation. This procedure had not yet been carried out due to the complexity of the procedure and the regional shortage of qualified professionals for this type of treatment.

Due to the slow growth of an ameloblastoma, recurrence often can only be diagnosed several years after the initial treatment. Thus, the clinical and radiographic monitoring of patients is recommended for a minimum of 10 years ${ }^{16-17}$.

\section{REFERENCES}

1. Ghandhi D, Ayoub AF, Pogrel MA, MacDonald G, Brocklebank LM, Moos KF. Ameloblastoma: a surgeon's dilemma. J Oral Maxillofac Surg. 2006;64(7):1010-4. doi: 10.1016/j. joms.2006.03.022

2. Ramesh RS, Manjunath S, Ustad TH, Pais S, Shivakumar K. Unicystic ameloblastoma of the mandible--an unusual case report and review of literature. Head Neck Oncol. 2010;2:1. doi: 10.1186/1758-3284-2-1

3. Amzerin M, Fadoukhair Z, Belbaraka R, Iraqui M, Boutayeb S, M'rabti $\mathrm{H}$, et al. Metastatic ameloblastoma responding to combination chemotherapy: case report and review of the literature. J Med Case Reports. 2011;5:491. doi: 10.1186/1752-1947-5-491

4. Ram R. Ameloblastoma relapse after 16 years of resection in symphysis of mandible sparing the bone graft. Natl J Maxillofac Surg. 2010;1(2):190-3. doi: 10.4103/0975-5950.79229

5. Kalaskar R, Unawane AS, Kalaskar AR, Pandilwar P. Conservative management of unicystic ameloblastoma in a young child: Report of two cases. Contemp Clin Dent. 2011;2(4):359-63. doi: 10.4103/0976-237X.91804

6. Carlson ER, Marx RE. The ameloblastoma: primary, curative surgical management. J Oral Maxillofac Surg. 2006;64(3):48494. doi:10.1016/j.joms.2005.11.032

7. Hertog D, Bloemena E, Aartman IH, van-der-Waal I. Histopathology of ameloblastoma of the jaws; some critical observations based on a 40 years single institution experience. Med Oral Patol Oral Cir Bucal. 2012;17(1):e76-82. doi: 10.4317/medoral.18006

8. Dolanmaz D, Etoz OA, Pampu A, Kalayci A, Gunhan O. Marsupialization of unicystic ameloblastoma: a conservative approach for aggressive odontogenic tumors. Indian J Dent Res. 2011;22(5):709-12. doi: 10.4103/0970-9290.93461

9. Natashekar M, Chowdhary R, Chandraker NK. Rehabilitation of recurrent unicystic ameloblastoma using distraction osteogenesis

\section{CONCLUSION}

Ameloblastomas have a high rate of local recurrence if not properly removed. Therefore, it is a paradox to recommend conservative treatment, especially in cases of large and expansive tumors. A radical surgical protocol with a good margin of safety should be adopted to prevent tumor recurrence.

\section{Collaborators}

CHC SOUZA, LLA SOUSA and JLM FÉ participated in the description of the case and writing the article. MSC BORBA and MCA LOPES performed the surgical procedure of the case and participated in the writing of the article. SSLV BARROS participated in the histological evaluation and written work review.

and dental implants. Niger J Clin Pract. 2011;14(4):486-91. doi: 10.4103/1119-3077.91763

10. Lau SL, Samman N. Recurrence related to treatment modalities of unicystic ameloblastoma: a systematic review. Int J Oral Maxillofac Surg. 2006;35(8):681-90. doi: 10.1016/j. ijom.2006.02.016

11. Hong J, Yun PY, Chung IH, Myoung H, Suh JD, Seo BM, et al. Long-term follow up on recurrence of 305 ameloblastoma cases. Int J Oral Maxillofac Surg. 2007;36(4):283-8. doi: 10.1016/j. ijom.2006.11.003

12. Nakamura N, Higuchi $Y$, Mitsuyasu $T$, Sandra F, Ohishi $M$. Comparison of long-term results between different approaches to ameloblastoma. Oral Surg Oral Med Oral Pathol Oral Radiol Endod. 2002;93(1):13-20. doi: 10.1067/moe.2002.119517

13. Tortorici S, Difalco P, Buzzanca ML, Burruano F. Management of primary ameloblastoma of the jaw: a 15 years' experience. Minerva Stomatol. 2012;61(5):175-82.

14. Olaitan AA, Adeola DS, Adekeye EO. Ameloblastoma: clinical features and management of 315 cases from Kaduna, Nigeria. J Craniomaxillofac Surg. 1993;21(8):351-5.

15. Bataineh $A B$. Effect of preservation of the inferior and posterior borders on recurrence of ameloblastomas of the mandible. Oral Surg Oral Med Oral Pathol Oral Radiol Endod. 2000;90(2):15563. doi: 10.1067/moe.2000.107971

16. Dandriyal R, Gupta A, Pant S, Baweja HH. Surgical management of ameloblastoma: Conservative or radical approach. Natl J Maxillofac Surg. 2011;2(1):22-7. doi: 10.4103/0975-5950.85849

17. Li TJ, Kitano M, Arimura K, Sugihara K. Recurrence of unicystic ameloblastoma: a case report and review of the literature. Arch Pathol Lab Med. 1998;122(4):371-4.

Received on: 12/12/2012

Final version resubmitted on: 20/7/2013

Approved on: 30/8/2013 